\title{
ANALISIS MODE SISTEM PEMBANGKIT LISTRIK TENAGA HIBRID MICROHYDRO-PHOTOVOLTAIC ARRAY MENGGUNAKAN HOMER (STUDI KASUS : KAMPUNG BAYANG JANIAH, KABUPATEN PESISIR SELATAN)
}

\author{
Novi Kurniasih ${ }^{1}$, Refdinal Nazir ${ }^{2}$ \\ ${ }^{1}$ Program Studi Magister Teknik Elektro, Universitas Andalas \\ ${ }^{2}$ Jurusan Teknik Elektro, Universitas Andalas \\ e-mail: novikurniasih88@yahoo.co.id
}

\begin{abstract}
Abstrak-Dalam penelitian ini membahas tentang optimisasi desain dan analisis ekonomi teknik dari Pembangkit Listrik Tenaga Hibrid Off-Grid Microhydro-Photovoltaic Array dengan menggunakan bantuan perangkat lunak HOMER 2 versi 2.81. Pemanfaatan sistem Pembangkit Listrik Tenaga Hibrid (PLTH) dapat mengatasi permasalahan kelistrikan di Kampung Bayang Janiah, Nagari Koto Ranah, Kecamatan Bayang Utara, Kabupaten Pesisir Selatan yaitu jauh dari jangkauan jaringan listrik PLN dan dapat meningkatkan keandalan secara ekonomis dimana awalnya listrik beroperasi hanya $12 \mathrm{jam} / \mathrm{hari}$ yang bersumber dari PLTMH saja, dapat ditingkatkan menjadi beroperasi penuh selama 24 jam/hari. Dari analisa yang telah dilakukan, diperoleh ketersediaan debit bulanan air sungai Bayang Janiah dengan menggunakan metode F. J. Mock yaitu debit andalan $90 \%$ sebesar $102 \mathrm{~L} / \mathrm{s}$ dengan head efektif $14 \mathrm{~m}$ mampu menggerakkan hydro turbine sehingga menghasilkan daya sekitar $11,3 \mathrm{~kW}$. Sementara itu, untuk sistem photovoltaic array menghasilkan daya sebesar 8,4 kW dengan jumlah modul surya sebanyak 84 modul dan jumlah battery $6 \mathrm{~V} 1.091$ Ah yang dibutuhkan sebanyak 8 unit serta bidirectional converter dengan total kapasitas sebesar $10 \mathrm{~kW}$, berjumlah 2 unit. Hasil simulasi HOMER menunjukkan bahwa penentuan konfigurasi desain sistem PLTH yang paling optimal untuk diterapkan di Kampung Bayang Janiah berdasarkan Total NPC terendah adalah integrasi antara microhydro-photovoltaic array-battery bank-bidirectional converter. Pada konfigurasi sistem yang optimal tersebut, kontribusi microhydro sebesar $78.945 \mathrm{kWh} / \mathrm{yr}$, photovoltaic array sebesar $11.404 \mathrm{kWh} / \mathrm{yr}$, dengan Total NPC sebesar \$ 146.041, Levelized COE sebesar \$ 0,525/kWh, sedangkan untuk konsumsi energi listrik per tahun sebesar $30.668 \mathrm{kWh}$ dan memiliki kelebihan energinya sebesar $59.608 \mathrm{kWh} / \mathrm{yr}$, sehingga dapat memenuhi kebutuhan listrik rumah tangga sebanyak $56 \mathrm{kk}$ termasuk juga sarana sosial yang ada di kampung tersebut.
\end{abstract}

Kata Kunci : PLTH Off-Grid Microhydro-Photovoltaic Array, Optimisasi Desain, Simulasi, HOMER, Total NPC, Levelized COE

\begin{abstract}
In this study discusses the optimization of the design and analysis of engineering economics Hybrid Power Plant Off-Grid Microhydro - Photovoltaic Array with the help of software HOMER 2 version 2.81. Utilization of Hybrid Power Plant System can overcome the electrical problems in Bayang Janiah village, Nagari Koto Ranah, Bayang Utara Subdistrict, Pesisir Selatan District that is far from the reach of the grid and can improve the reliability of electricity economically in which initially operated only 12 hours/day sourced from microhydro power plant only, can be upgraded to full operation 24 hours/day. From the analysis that has been conducted, obtained monthly discharge of Bayang Janiah river availability using dependable discharge F. J. Mock $90 \%$ of $102 \mathrm{~L} / \mathrm{s}$ to $14 \mathrm{~m}$ of effective head is able to move the hydro turbine to produce power of about $11,3 \mathrm{~kW}$. Meanwhile, for an array of photovoltaic systems produce power equal to $8.4 \mathrm{~kW}$ with a number of solar modules by 84 modules and the number of battery $6 \mathrm{~V} 1.091 \mathrm{Ah}$ required 8 units and a bidirectional converter with a total capacity of $10 \mathrm{~kW}$, totaling 2 units. HOMER simulation results show that the determination of the configuration of the hybrid power plant system design most optimal for application in Bayang Janiah village lowest Total NPC is based on the integration between microhydro - photovoltaic array - battery bank - bidirectional converter. On the optimal system configuration, microhydro contribution of $78.945 \mathrm{kWh} / \mathrm{yr}$, a photovoltaic array of $11.404 \mathrm{kWh} / \mathrm{yr}$, with a Total NPC of $\$ 146.041$, Levelized COE of $\$ 0,525 / \mathrm{kWh}$, while the electrical energy consumption of 30.668 $\mathrm{kWh}$ per year and has excess energy of $59.608 \mathrm{kWh} / \mathrm{yr}$, so it can meet the needs of household electricity to 56 households as well as social facilities in the village.
\end{abstract}

Keywords : Off-Grid Hybrid Power System Microhydro-Photovoltaic Array, Optimization Design, Simulation, HOMER, Total NPC, Levelized COE 


\section{PENDAHULUAN}

Sesuai dengan Peraturan Presiden RI no. 5 tahun 2006 tentang Kebijakan Energi Nasional (KEN) yaitu pangsa pasar energi baru dan terbarukan dalam konsumsi energi nasional tahun 2025 ditargetkan mencapai 17\%[1]. Namun demikian pemerintah Indonesia ingin mencapai target yang lebih tinggi dengan mencanangkan visi energi 25/25, dimana pemerintah berkomitmen meningkatkan penggunaan energi baru dan terbarukan sampai $25 \%$ dari keseluruhan konsumsi energi pada tahun 2025 dan juga tercapainya elastisitas energi lebih kecil dari satu[2].

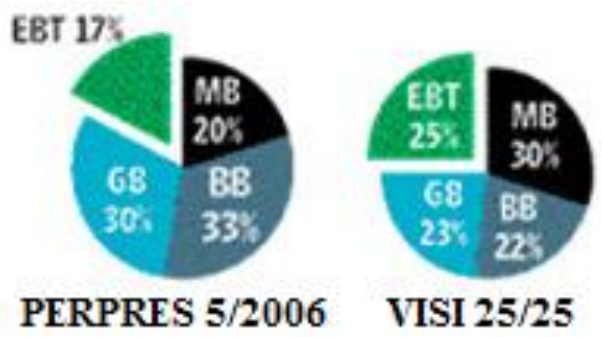

\section{Gambar 1. Grafik Arah Kebijakan Energi Nasional[2]}

Di Indonesia terutama Provinsi Sumatera Barat, masih banyak pedesaan terpencil yang belum terlistriki karena tidak terjangkau oleh jaringan listrik PLN. Ini terbukti masih terdapatnya beberapa kabupaten di Sumatera Barat yang memiliki ratio elektrifikasi (RE) di bawah 66\%[4]. Namun demikian ratio elektrifikasi untuk Provinsi Sumatera Barat sendiri berdasarkan data ratio elektrifikasi tahun 2013 sudah mencapai 75,76\%[4],[5]. Walaupun beberapa kabupaten di Sumatera Barat memiliki ratio elektrifikasi di bawah $66 \%$, tetapi kawasan pedesaan yang ada di kabupaten tersebut memiliki sumber energi terbarukan yang dapat dikembangkan sebagai sumber energi listrik alternatif[4].

Salah satu potensi sumber energi terbarukan yang cukup besar ketersediaannya di Sumatera Barat adalah energi air yang dapat dikelola untuk menjadi Pembangkit Listrik Tenaga Mikrohidro[4]. Pembangkit Listrik Tenaga Mikrohidro tersebut berperan serta dalam melestarikan lingkungan, minimal di sepanjang Daerah Aliran Sungai (DAS) sumber air, ditengah menggebu-gebunya pembalakkan hutan dan pembukaan kawasan perkebunan yang tidak ramah lingkungan.

Selain sumber energi air, potensi energi terbarukan yang cukup mudah dalam pemanfaatannya dan ketersediaannya yaitu energi surya. Wilayah Indonesia terletak di garis khatulistiwa, sehingga memperoleh penyinaran matahari rata-rata 8 jam/hari dengan intensitas radiasi matahari rata-rata sekitar 4,80 $\mathrm{kWh} / \mathrm{m}^{2} /$ hari[3]. Sumber energi surya ini dapat dikembangkan menjadi Pembangkit Listrik Tenaga Sel Surya yang merupakan salah satu solusi yang dapat dipertimbangkan sebagai salah satu pembangkit listrik alternatif[8]. Pemanfaatan sumber energi surya tersebut untuk kelistrikan belum secara optimal, baru sekitar 42,78 MW[2]. Sayangnya biaya investasi Pembangkit Listrik Tenaga Sel Surya masih lebih mahal apabila dibandingkan dengan biaya investasi pembangkit listrik berbahan bakar fosil, karena sampai saat ini photovoltaic cell yang berfungsi untuk mengkonversi energi matahari menjadi energi listrik, masih diimpor dari negara lain dan efisiensi dari photovoltaic module hanya sebesar $17 \%$ yang menyebabkan harga Pembangkit Listrik Tenaga Sel Surya tiap kiloWatt-nya masih sangat tinggi[8].

Teknologi Pembangkit Listrik Tenaga Sel Surya termasuk teknologi yang ramah lingkungan karena tidak melepaskan polutan seperti halnya pembangkit listrik berbahan bakar fosil dan tidak menghasilkan noise (kebisingan)[6],[8]. Untuk kekontinuan ketersediaan listrik dan pemanfaatan energi listrik sel surya (solar photovoltaic) secara maksimal terutama di daerah-daerah terpencil, maka sangat diperlukan sistem hibridisasi.

Sistem Pembangkit Listrik Tenaga Hibrid merupakan salah satu solusi untuk mengatasi krisis energi listrik yang terjadi saat ini. Penggabungan sumber energi mikrohidro dengan energi sel surya (solar photovoltaic) dapat meningkatkan waktu layanan listrik secara ekonomis sehingga beban listrik masyarakat daerah terpencil dapat dipenuhi secara optimal[12]. Adapun kendala utama yang dihadapi dalam pemanfaatan pembangkit listrik tenaga hibrid ini adalah efisiensi energi listrik yang dihasilkan sistem sangat dipengaruhi oleh kondisi lingkungan.

Untuk mengetahui kelayakan potensi Pembangkit Listrik Tenaga Hibrid di Provinsi Sumatera Barat khususnya di Kabupaten Pesisir 
Selatan, maka dilakukan penelitian mengenai optimisasi sistem yang ekonomis dari Pembangkit Listrik Tenaga Hibrid Microhydro-Photovoltaic Array dengan melakukan desain pemodelan menggunakan bantuan perangkat lunak HOMER, dimana ketentuannya berdasarkan Total NPC terendah. Kabupaten Pesisir Selatan merupakan salah satu kabupaten yang memiliki ratio elektrifikasi yang rendah yaitu sebesar $61,68 \%$ berdasarkan data ratio elektrifikasi tahun 2013[5]. Diharapkan dari hasil penelitian ini dapat digunakan sebagai acuan dalam menentukan kelayakan dan pengoptimalan pembangkit listrik alternatif dengan sumber energi terbarukan tersebut sehingga dapat memberikan kontribusi yang signifikan terhadap kebutuhan energi listrik daerah-daerah terpencil/pedesaan di Kabupaten Pesisir Selatan, seperti di Kampung Bayang Janiah, Nagari Koto Ranah, Kecamatan Bayang Utara yang jauh dari jangkauan jaringan listrik PLN. Ke depannya diharapkan dapat meningkatkan keandalan secara ekonomis dimana awalnya listrik beroperasi hanya 12 jam per hari yang bersumber dari PLTMH saja, dapat ditingkatkan menjadi beroperasi penuh selama 24 jam per hari.

\section{TINJAUAN PUSTAKA}

\subsection{Pembangkit Listrik Tenaga Hibrid}

Pembangkit Listrik Tenaga Hibrid (PLTH) didefinisikan sebagai suatu sistem pembangkit tenaga listrik yang menggabungkan dua atau lebih pembangkit dengan sumber energi yang berbeda, umumnya digunakan untuk isolated grid, sehingga diperoleh sinergi yang memberikan keuntungan ekonomis maupun teknis[12].

Beberapa kelebihan yang dapat diperoleh dari konfigurasi sistem Pembangkit Listrik Tenaga Hibrid ini adalah sebagai berikut[12]:

a. Solusi untuk mengatasi krisis bahan bakar minyak bumi

b. Beban listrik dapat dipenuhi secara optimal terutama di daerah-daerah terpencil/pedesaan yang jauh dari jangkauan jaringan listrik PLN

c. Meningkatkan efisiensi ekonomi pembangkit

d. Meningkatkan keandalan (reliability) sistem pembangkit

e. Meningkatkan waktu layanan listrik secara ekonomis

f. Meningkatkan umur operasi sistem g. Tidak menimbulkan polusi dan limbah (ramah lingkungan)

h. Biaya pengoperasian dan pemeliharaannya relatif murah

i. Biaya produksi energi listrik atau Cost of Energy $(\mathrm{Rp} / \mathrm{kWh})$ per tahun relatif murah.

Disamping kelebihan-kelebihan di atas konfigurasi sistem Pembangkit Listrik Tenaga Hibrid tersebut juga mempunyai beberapa kekurangan, diantaranya[13],[14]:

a. Produksi energi baru dan terbarukan sangat tergantung pada siklus alam

b. Biaya investasi awal sistem ini lebih mahal

c. Tidak dapat menangani beban puncak dengan baik tanpa penyimpanan energi.

Adapun konfigurasi dasar dari sistem Pembangkit Listrik Tenaga Hibrid tersebut dapat dikelompokkan menjadi tiga yakni [15]:

a. Sistem hibrid seri

b. Sistem hibrid paralel

c. Sistem hibrid switched.

Dalam penelitian ini, konfigurasi sistem hibrid yang digunakan adalah kombinasi sistem hibrid switched. Skema dari pembangkit listrik tenaga hibrid microhydro-photovoltaic array tersebut dapat dilihat pada gambar berikut ini.

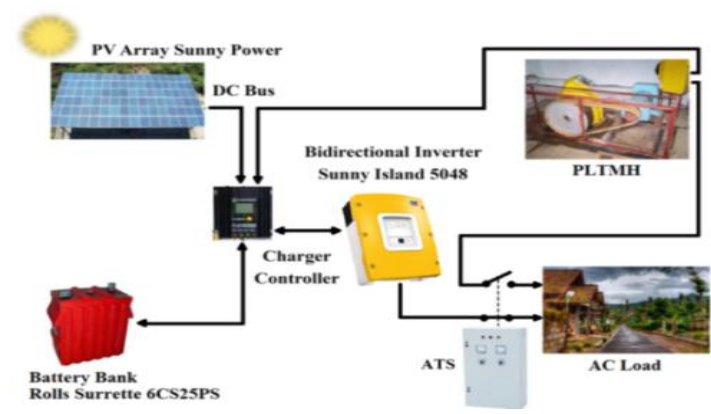

Gambar 2. Skema PLTH MicrohydroPhotovoltaic Array

\subsection{HOMER}

HOMER (Hybrid Optimization Model for Energy Renewable) merupakan suatu perangkat lunak (program) simulasi yang mengoptimalkan sistem pembangkit tenaga listrik, baik off-grid (stand-alone) maupun grid-connected yang dapat terdiri atas kombinasi photovoltaic, mikrohidro, battery dan kombinasi sumber energi baru dan terbarukan lainnya serta untuk 
melayani beban listrik maupun beban thermal[16].

Perangkat lunak HOMER ini dikembangkan oleh The National Renewable Energy Laboratory (NREL), USA yang bekerjasama dengan Mistaya Engineering, dimana hak ciptanya dilindungi oleh Midwest Research Institute (MRI) dan digunakan oleh Departemen Energi Amerika Serikat (DOE)[17].

HOMER memiliki beberapa keunggulan dibandingkan dengan perangkat lunak yang serupa lainnya, yakni[16]:

a. Dapat mengetahui hasil yang optimal dari konfigurasi sistem (mensimulasikan beberapa konfigurasi sistem berdasarkan Net Present Cost)

b. Dapat menunjukkan analisis nilai sensitivitas

c. Dapat memodelkan sistem jaringan transmisi listrik

d. Komponen-komponen sistem hibrid yang akan digunakan lengkap

e. Dapat memodelkan sumber energi baru dan terbarukan yang tersedia

f. Parameter-parameter input sangat terperinci, seperti: sumber energi baru dan terbarukan, faktor ekonomi, emisi, constraints dan lain-lain.

Arsitektur perangkat lunak HOMER memiliki tiga bagian utama, yaitu: input, simulasi dan output seperti yang dapat dilihat pada skema di bawah ini.

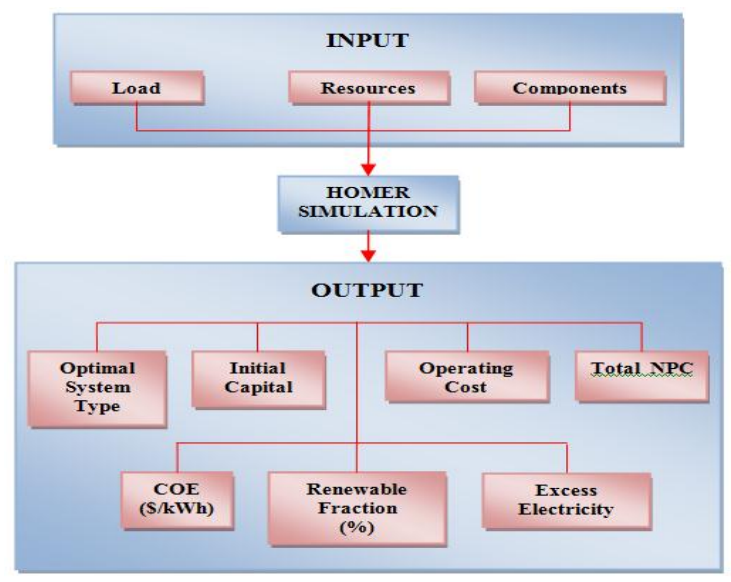

Gambar 3. Arsitektur Simulasi dan Optimasi HOMER[12],[15]

\section{METODOLOGI PENELITIAN}

Langkah-langkah mendesain sistem Pembangkit Listrik Tenaga Hibrid Microhydro
-Photovoltaic Array dengan perangkat lunak HOMER ini, membutuhkan beberapa data yang mana data-data tersebut terlebih dahulu dianalisa secara matematis, seperti yang dapat ditunjukkan dalam diagram alir penelitian berikut ini.

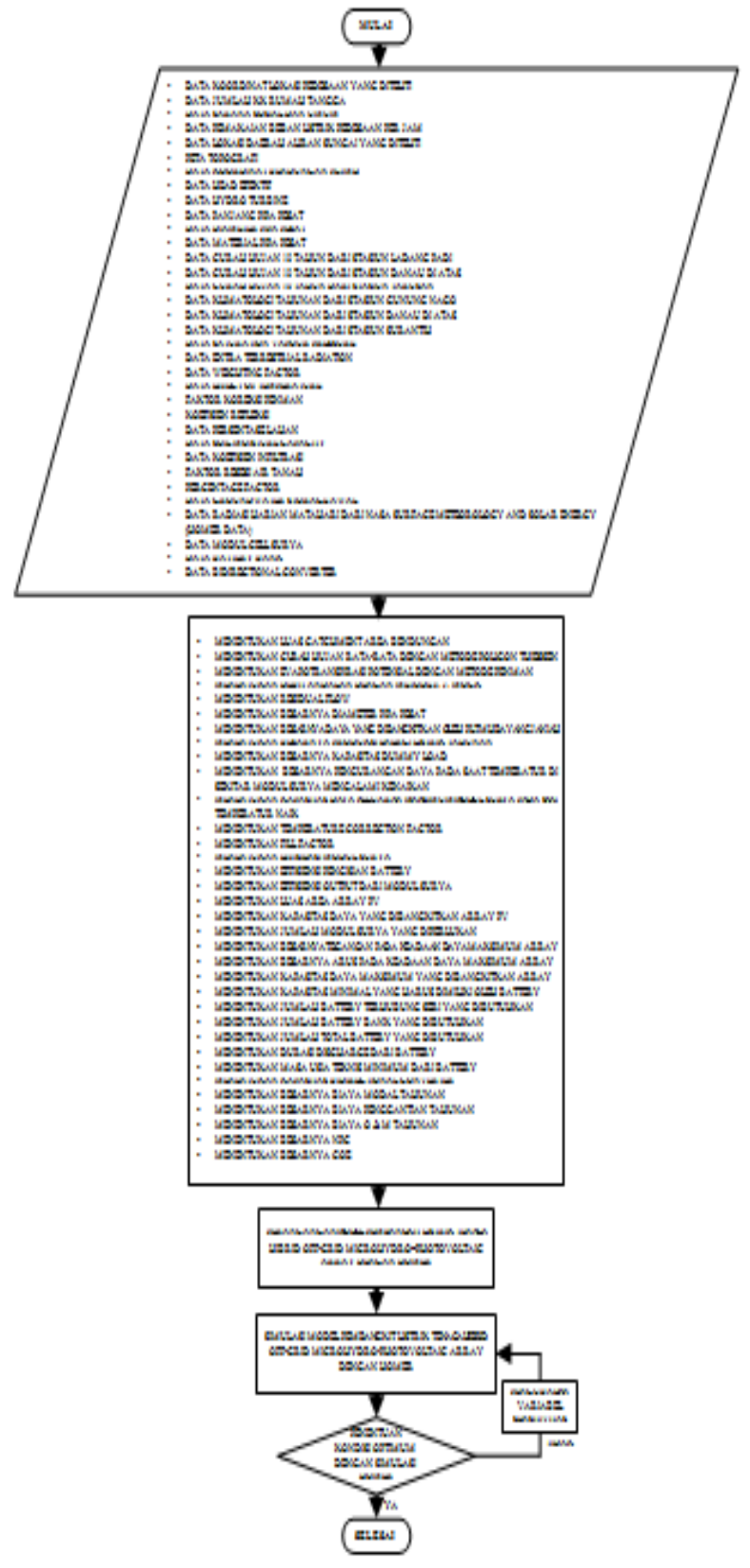

Adapun komponen-komponen dari sistem Pembangkit Listrik Tenaga Hibrid Microhydro-Photovoltaic Array untuk melayani beban listrik masyarakat Kampung Bayang Janiah yang diinputkan ke dalam perangkat lunak HOMER, seperti yang dapat dilihat pada gambar berikut ini. 


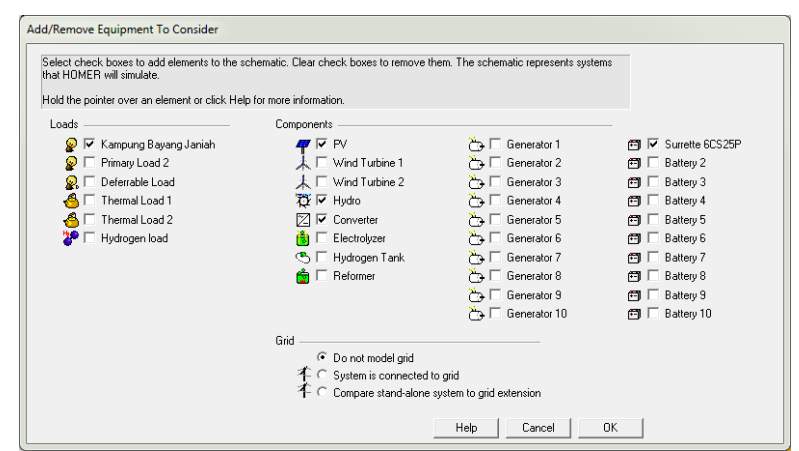

Gambar 4. Komponen-komponen Input PLTH Microhydro-Photovoltaic Array

Pada penelitian ini, pemodelan sistem Pembangkit Listrik Tenaga Hibrid off-grid berdasarkan potensi energi terbarukan yang tersedia di Kampung Bayang Janiah. Pemodelan sistem hibrid tersebut terdiri atas: hydro turbine, modul photovoltaic dan juga didukung oleh battery sebagai media penyimpan energi. Data dari berbagai parameter seperti: potensi sumber energi air dan energi matahari, profil pemakaian beban listrik oleh masyarakat serta keterangan komponen dari berbagai parameter, yakni: ukuran, jumlah dan biaya dari hydro turbine, modul photovoltaic, battery, converter, yang telah diperoleh dari berbagai sumber untuk diinputkan ke dalam skema perencanaan sistem Pembangkit Listrik Tenaga Hibrid off-grid.

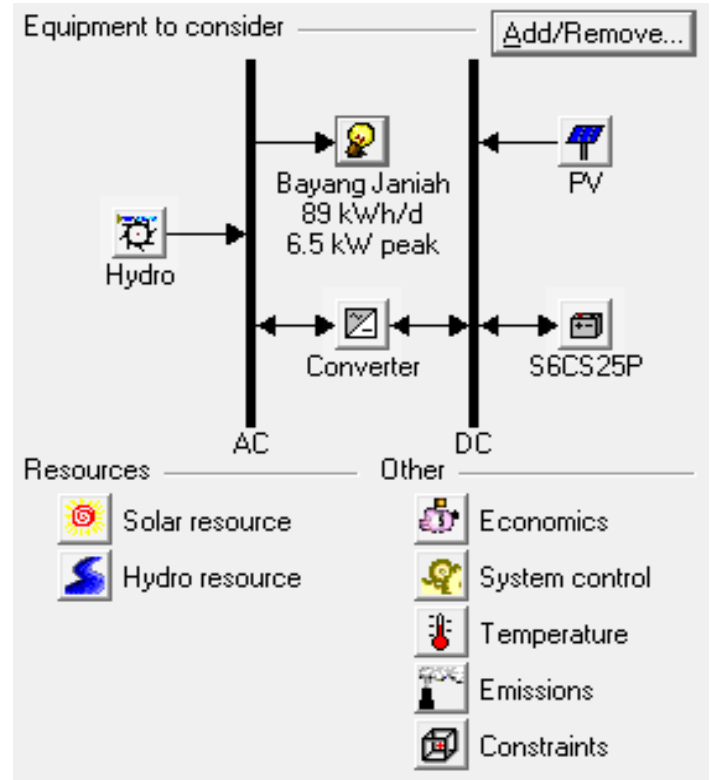

Gambar 5. Sistem Pembangkit Listrik Tenaga Hibrid Off-Grid Microhydro - Photovoltaic Array
Beban puncak siang hari terjadi antara pukul 09.00 - $12.00 \mathrm{WIB}$ sebesar 4,569 kW, dimana beban AC sangat mendominasi. Sementara itu untuk beban puncak malam hari terjadi antara pukul $19.00-20.00$ WIB sebesar $8,060 \mathrm{~kW}$, dimana beban listrik didominasi oleh beban AC dan lampu penerangan. Pada saat weekdays, konsumsi rata-rata energi listrik sebesar $89 \mathrm{kWh} /$ day.

Tabel 1. Pemakaian Beban Listrik Weekdays

Kampung Bayang Janiah

\begin{tabular}{|c|r|}
\hline \multicolumn{1}{|c|}{ Hour } & Load $(\mathrm{kW})$ \\
\hline $00: 00 \cdot 01: 00$ & 3.030 \\
\hline $01: 00 \cdot 02: 00$ & 3.030 \\
\hline $02: 00 \cdot 03: 00$ & 3.030 \\
\hline $03: 00 \cdot 04: 00$ & 3.030 \\
\hline $04: 00 \cdot 05: 00$ & 3.110 \\
\hline $05: 00 \cdot 06: 00$ & 3.130 \\
\hline $06: 00 \cdot 07: 00$ & 1.790 \\
\hline $07: 00 \cdot 08: 00$ & 0.080 \\
\hline $08: 00 \cdot 09: 00$ & 3.560 \\
\hline $09: 00 \cdot 10: 00$ & 4.569 \\
\hline $10: 00 \cdot 11: 00$ & 4.569 \\
\hline $11: 00 \cdot 12: 00$ & 4.569 \\
\hline $12: 00 \cdot 13: 00$ & 3.144 \\
\hline $13: 00 \cdot 14: 00$ & 4.484 \\
\hline $14: 00 \cdot 15: 00$ & 3.910 \\
\hline $15: 00 \cdot 16: 00$ & 3.970 \\
\hline $16: 00 \cdot 17: 00$ & 3.560 \\
\hline $17: 00 \cdot 18: 00$ & 1.790 \\
\hline $18: 00 \cdot 19: 00$ & 3.130 \\
\hline $19: 00 \cdot 20: 00$ & 8.060 \\
\hline $20: 00 \cdot 21: 00$ & 6.830 \\
\hline $21: 00 \cdot 22: 00$ & 6.830 \\
\hline $22: 00 \cdot 23: 00$ & 3.030 \\
\hline $23: 00 \cdot 00: 00$ & 3.030 \\
\hline & \\
\hline
\end{tabular}

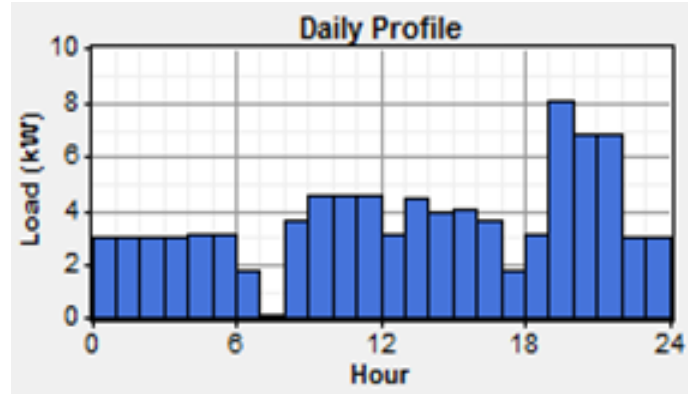

Gambar 6. Profil Beban Listrik Weekdays Kampung Bayang Janiah 
Tabel 2. Sistem Beban Listrik Weekdays

\begin{tabular}{|l|r|r|}
\hline & Baseline & \multicolumn{1}{|c|}{ Scaled } \\
\hline Average (kW/d) & 89.0 & 89.0 \\
\hline Average (kW) & 3.71 & 3.71 \\
\hline Peak (kW) & 9.86 & 6.54 \\
\hline Load factor & 0.567 & 0.567 \\
\hline
\end{tabular}

Untuk PLTMH memanfaatkan potensi sungai Bayang Janiah. Sungai Bayang Janiah terletak pada koordinat $01^{\circ} 07^{\prime} 56^{\prime \prime} \mathrm{LS}$ $100^{\circ} 36^{\prime} 06,4^{\prime \prime}$ BT dan merupakan salah satu sub DAS dari Batang Bayang. Pemetaan DAS Batang Bayang menggunakan software MapInfo Professional 10.5[22], yang dapat dilihat pada gambar-gambar berikut.

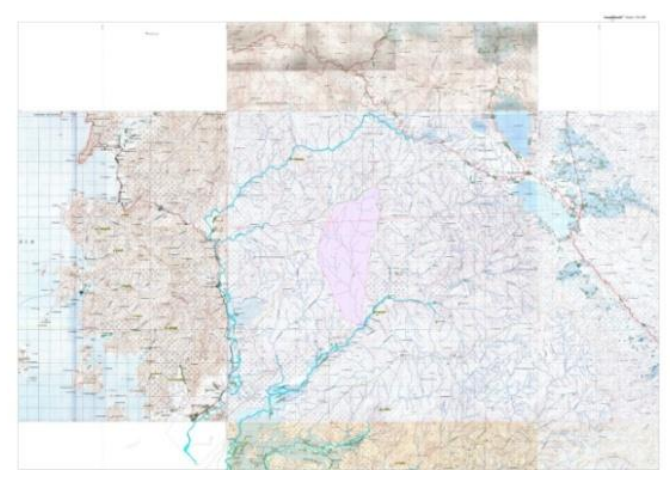

Gambar 7. Peta DAS Batang Bayang[22]

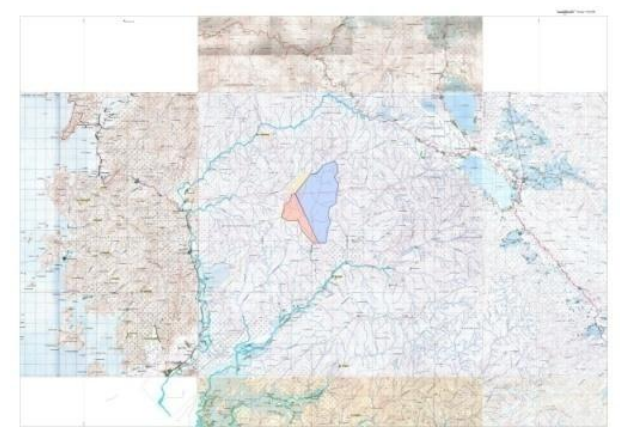

Gambar 8.Peta Luas Catchment Area Bendungan PLTMH Bayang Janiah[22]

Hasil perhitungan debit andalan sub DAS Bayang Janiah yang diperlukan untuk kebutuhan PLTMH dapat dilihat pada tabel berikut:
Tabel 3. Persentase Keandalan Untuk DebitDesain PLTMH Bayang Janiah

\begin{tabular}{|c|c|}
\hline $\begin{array}{c}\text { Probabilitas Keandalan } \\
(\boldsymbol{\%})\end{array}$ & $\begin{array}{c}\mathbf{Q} \\
\left(\mathbf{m}^{\mathbf{3}} \mathbf{\text { detik }}\right)\end{array}$ \\
\hline 0 & 5.828 \\
\hline 5 & 2.570 \\
\hline 10 & 1.836 \\
\hline 15 & 1.627 \\
\hline 20 & 1.482 \\
\hline 25 & 1.254 \\
\hline 30 & 1.051 \\
\hline 35 & 0.952 \\
\hline 40 & 0.81 \\
\hline 45 & 0.696 \\
\hline 50 & 0.553 \\
\hline 55 & 0.463 \\
\hline
\end{tabular}

Tabel 4. Persentase Keandalan Untuk Debit Desain PLTMH Bayang Janiah (Lanjutan)

\begin{tabular}{|c|c|}
\hline $\begin{array}{c}\text { Probabilitas Keandalan } \\
(\mathbf{\%})\end{array}$ & $\begin{array}{c}\mathbf{Q} \\
\left(\mathbf{m}^{3} / \text { detik }\right)\end{array}$ \\
\hline 60 & 0.396 \\
\hline 65 & 0.334 \\
\hline 70 & 0.249 \\
\hline 75 & 0.199 \\
\hline 80 & 0.166 \\
\hline 85 & 0.127 \\
\hline 86 & 0.119 \\
\hline 87 & 0.119 \\
\hline 88 & 0.112 \\
\hline 89 & 0.103 \\
\hline 90 & 0.102 \\
\hline 95 & 0.08 \\
\hline 100 & 0.012 \\
\hline \multicolumn{2}{|c}{}
\end{tabular}

Sedangkan bentuk kurva durasi debit (Flow Duration Curve)-nya adalah sebagai berikut:

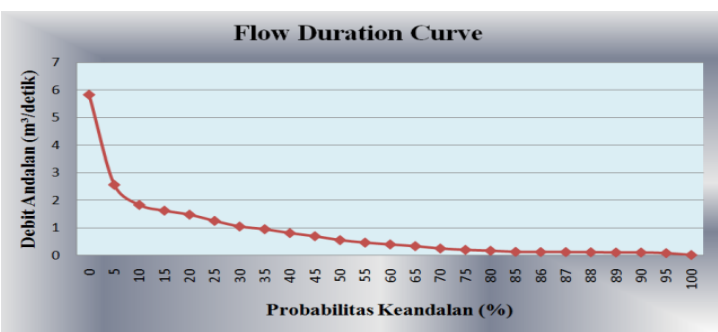

Gambar 9. Kurva Persentase Durasi Debit (Flow Duration Curve) 
Untuk input masing-masing komponen ke dalam perangkat lunak HOMER, dapat dilihat pada gambar berikut ini.

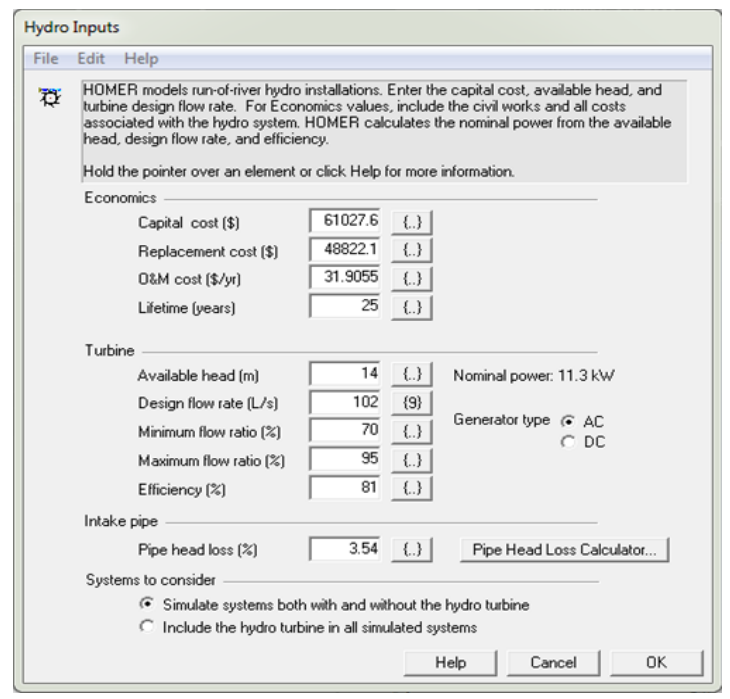

Gambar 10. Input Parameter Hydro Turbine

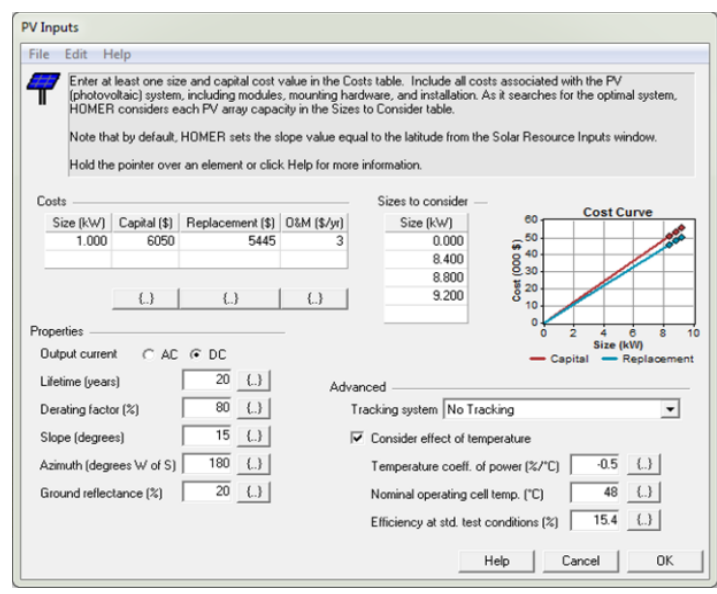

Gambar 11. Input Parameter Modul Surya

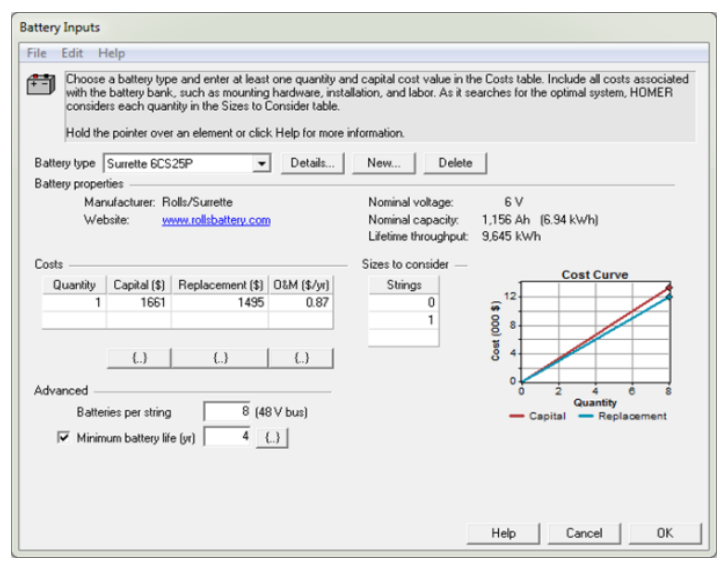

Gambar 12. Input Parameter Battery
Gambar berikut memperlihatkan rincian spesifikasi teknik dari battery Rolls Surrette 6CS25P.

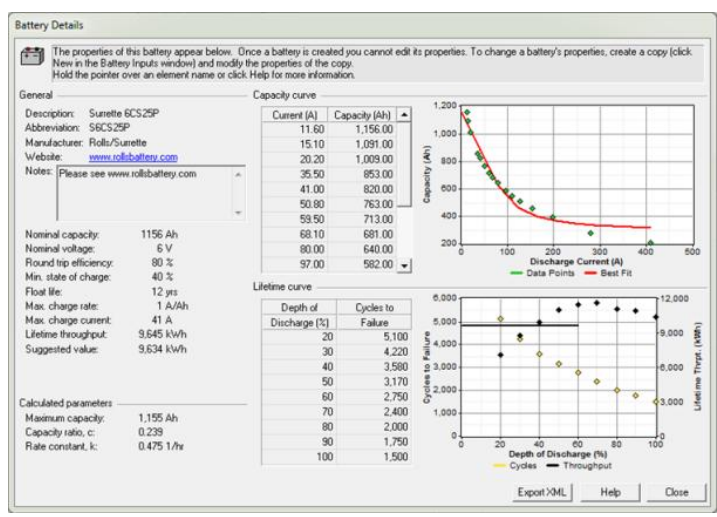

Gambar 13. Technical Data Battery Rolls Surrette 6CS25P[16]

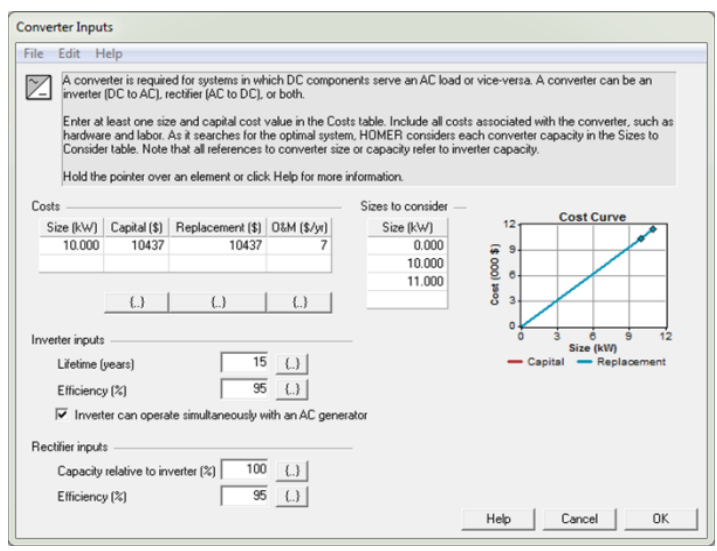

Gambar 14. Input Parameter Bidirectional Converter

\section{HASIL DAN PEMBAHASAN}

\subsection{Optimization Results}

Hasil simulasi dengan bantuan perangkat lunak HOMER memperlihatkan optimization results sebagai berikut:

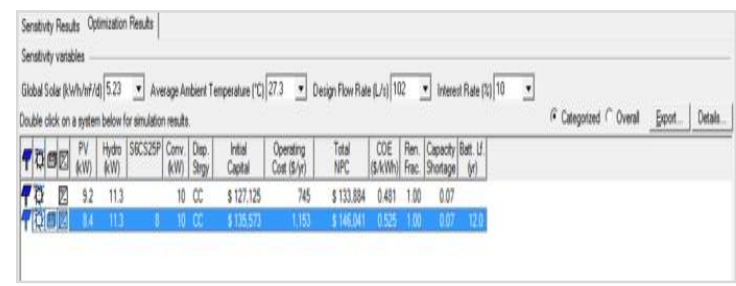

Gambar 15. Pilihan I 


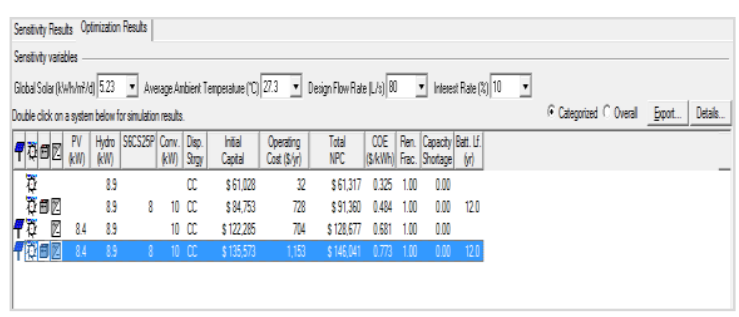

Gambar 16. Pilihan II

Apabila parameter design flow rate dan annual real interest rate ditingkatkan hingga mencapai nilai maksimum yang ditetapkan berdasarkan masing-masing sensitivity values yang diinputkan ke dalam HOMER, maka memberikan pengaruh terhadap sistem pembangkit listrik tenaga hibrid tersebut dimana Operating Cost (\$/yr) dan Total NPC (\$) yang semakin rendah sebaliknya Levelized $\mathrm{COE}$ $(\$ / \mathrm{kWh})$ yang semakin tinggi.

\subsection{Sensitivity Results}

Sensitivity results diperlihatkan melalui suatu grafik tipe sistem yang optimal, seperti pada gambar berikut:

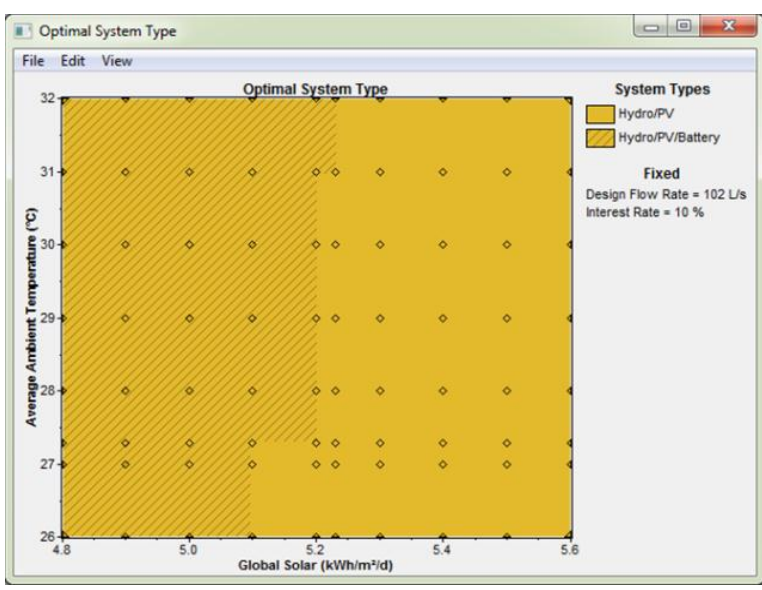

Gambar 17. Sensitivity Results

Berdasarkan grafik pada gambar di atas, diketahui bahwa tipe sistem yang paling optimal dipilihkan HOMER yaitu:

a. Sistem hibrid microhydro-photovoltaic array-battery, dimana sistem ini merupakan sistem pertama yang dipilihkan HOMER sebagai sistem yang paling optimal dengan posisi global solar berada di kisaran:

- 4,80 - 5,09 $\mathrm{kWh} / \mathrm{m}^{2} / \mathrm{d}$ dengan ambient temperature rata-rata berada di rentang $26,0^{\circ} \mathrm{C}-27,4^{\circ} \mathrm{C}$
- 4,80 - 5,20 $\mathrm{kWh} / \mathrm{m}^{2} / \mathrm{d}$ dengan ambient temperature rata-rata berada di rentang $27,4^{\circ} \mathrm{C}-31,0^{\circ} \mathrm{C}$

- 4,80 - 5,23 $\mathrm{kWh} / \mathrm{m}^{2} / \mathrm{d}$ dengan ambient temperature rata-rata berada di rentang $31,0^{\circ} \mathrm{C}-32,0^{\circ} \mathrm{C}$

b. Sistem hibrid microhydro-photovoltaic array, dimana sistem ini merupakan sistem kedua yang dipilihkan HOMER sebagai sistem yang paling optimal dengan posisi global solar berada di kisaran:

- 5,09 - 5,60 $\mathrm{kWh} / \mathrm{m}^{2} / \mathrm{d}$ dengan ambient temperature rata-rata berada di rentang $26,0^{\circ} \mathrm{C}-27,4^{\circ} \mathrm{C}$

- 5,20 - 5,60 $\mathrm{kWh} / \mathrm{m}^{2} / \mathrm{d}$ dengan ambient temperature rata-rata berada di rentang $27,4^{\circ} \mathrm{C}-31,0^{\circ} \mathrm{C}$

- 5,23 - 5,60 $\mathrm{kWh} / \mathrm{m}^{2} / \mathrm{d}$ dengan ambient temperature rata-rata berada di rentang $31,0^{\circ} \mathrm{C}-32,0^{\circ} \mathrm{C}$

Seperti yang terlihat pada grafik (Gambar 17), untuk sistem hibrid microhydro-photovoltaic array ini dimana sebagian besar posisi global solar berada di atas rata-rata radiasi harian. Dengan posisi global solar di atas rata-rata radiasi harian tersebut maka photovoltaic array dapat menghasilkan kapasitas daya yang besar karena adanya penyerapan energi yang cukup besar oleh photovoltaic array sehingga dengan demikian pada sistem hibrid microhydro-photovoltaic array tersebut tidak diperlukan penggunaan battery sebagai back-up dalam melayani suplai listrik ke beban.

\subsection{Electrical Simulation Results}

Dari hasil optimisasi di atas maka diperoleh desain sistem pembangkit listrik tenaga hibrid yang paling optimal sehingga dengan demikian hasil simulasi bagian electrical-nya dapat diperlihatkan pada gambar berikut ini. 


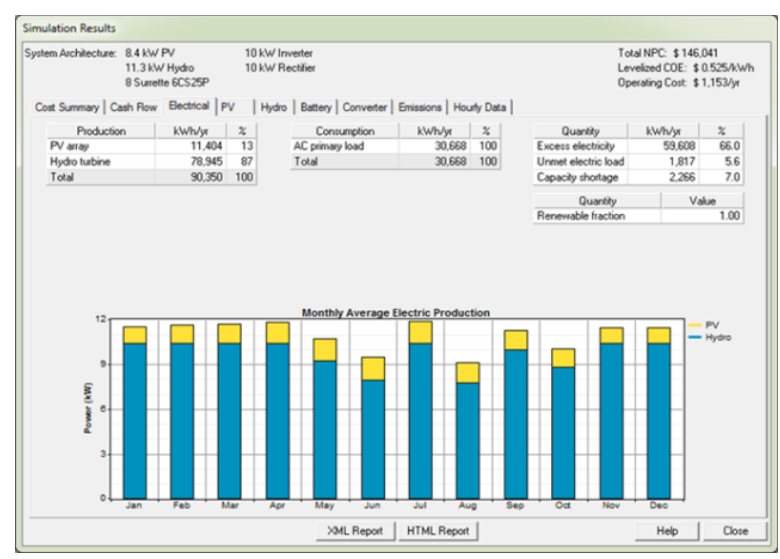

Gambar 18 Electrical Simulation Results

Grafik pada gambar berikut ini menunjukkan hasil simulasi gabungan komponen tiap jam pada tanggal 8 November. Dipilihnya tanggal 8 November karena kondisi dari photovoltaic array pada hari tersebut menghasilkan output power yang lebih rendah, sedangkan output power dari microhydro yang lebih tinggi dan persentase state of charge dari battery bank-nya berada dalam kondisi $100 \%$. Seperti yang terlihat pada Gambar 19, dimana pada tanggal 8 November output power dari photovoltaic array lebih rendah dari beban listrik AC sehingga kebutuhan listrik untuk melayani beban listrik AC masyarakat Kampung Bayang Janiah disuplai oleh microhydro system maupun battery bank. Pengisian battery bank ini dapat juga dilakukan oleh microhydro system.

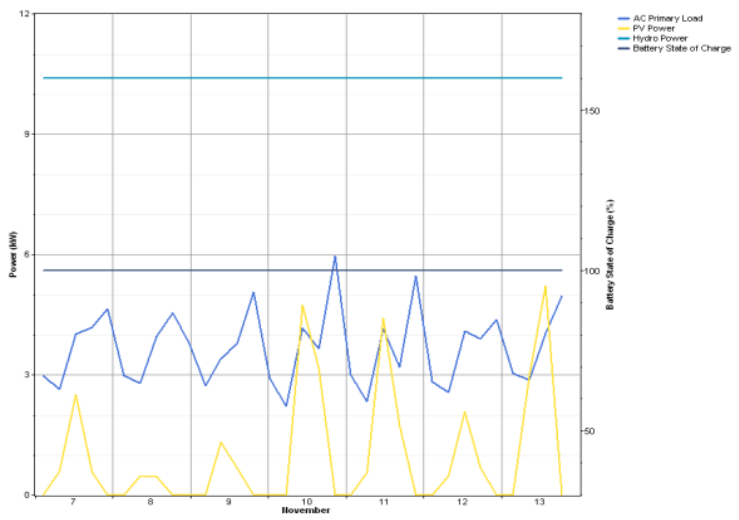

Gambar 19 Output Sistem Pembangkit Listrik Tenaga Hibrid Off-Grid Microhydro-Photovoltaic array

\section{KESIMPULAN}

Setelah dilakukan simulasi optimisasi desain Pembangkit Listrik Tenaga Hibrid offgrid Microhydro - Photovoltaic Array dengan menggunakan bantuan perangkat lunak HOMER 2 versi 2.81, maka dapat ditarik beberapa kesimpulan sebagai berikut:

1. Sistem Pembangkit Listrik Tenaga Hibrid yang paling optimal dalam mensuplai listrik untuk masyarakat Kampung Bayang Janiah, Nagari Koto Ranah, Kecamatan Bayang Utara yaitu kombinasi microhydro photovoltaic array - battery - converter, dengan rinciannya sebagai berikut: 1 unit hydro turbine yang digerakkan dengan debit desain air sungai sebesar 102 liter/detik dan head efektif-nya 14 meter menghasilkan kapasitas 11,3 kW, photovoltaic array berkapasitas $8,4 \mathrm{~kW}, 8$ unit battery $6 \mathrm{~V} 1.091 \mathrm{Ah}$ dan $10 \mathrm{~kW}$ bidirectional converter. Konfigurasi tersebut ditetapkan sebagai yang paling optimal berdasarkan nilai Total NPC terendah yaitu sebesar $\$ 146.041$ dan Levelized COE sebesar $\$ 0,525 / \mathrm{kWh}$ dengan Initial Capital yang diperlukan untuk merealisasikan sistem Pembangkit Listrik Tenaga Hibrid Microhydro - Photovoltaic Array tersebut adalah sebesar \$135.573.

2. Hasil simulasi dari optimisasi desain sistem hibrid microhydro dengan photovoltaic array ini menunjukkan bahwa kontribusi energi listrik yang diproduksi oleh microhydro sebesar $78.945 \mathrm{kWh} / \mathrm{yr}(87 \%)$ dan energi listrik yang diproduksi oleh photovoltaic array sebesar $11.404 \mathrm{kWh} / \mathrm{yr}$ (13\%), sehingga dengan kontribusi total sebesar $100 \%$ tersebut dapat melayani kebutuhan energi listrik harian masyarakat Kampung Bayang Janiah sebesar 88,692 $\mathrm{kWh}$ dan kebutuhan energi listrik per tahunnya sebesar $30.668 \mathrm{kWh}$. Ditinjau dari segi keandalan sistem hibridnya masih terjaga melihat capacity shortage per tahun yang dihasilkan oleh sistem dalam kisaran 7 $-8 \%$

3. Dengan diimplementasikannya sistem Pembangkit Listrik Tenaga Hibrid Microhydro-Photovoltaic Array di Kampung Bayang Janiah, Nagari Koto Ranah, Kecamatan Bayang Utara, 
Kabupaten Pesisir Selatan maka pemukiman perumahan yang dihuni oleh sebanyak 56 kepala keluarga termasuk juga sarana sosialnya dapat menikmati listrik selama 24 jam, dimana sebelumnya masyarakat setempat hanya menikmati listrik dari pukul 18.00 - 06.00 WIB yang bersumber dari PLTMH saja. Disamping itu, keuntungan lainnya dapat mengeliminasi ketergantungan terhadap bahan bakar minyak bumi dalam pembangkitan energi listrik sehingga berdampak terhadap berkurangnya pencemaran udara akibat emisi $\mathrm{CO}_{2}$.

\section{DAFTAR PUSTAKA}

[1] Peraturan Presiden Republik Indonesia No. 5 Tahun 2006 tentang Kebijakan Energi Nasional, 25 Januari 2006.

[2] Kementerian Energi dan Sumber Daya Mineral. (2013, Februari 8). Indonesia Energy Outlook 2012 [Online]. Available: http://www.esdm.go.id/publikasi/indonesi a-energy-outlook.html

[3] Sitompul, Rislima, Manual Pelatihan Teknologi Energi Terbarukan yang Tepat Untuk Aplikasi di Masyarakat Pedesaan. Jakarta : PNPM Support Facility (PSF), 2011, hal.45-75, 175-255.

[4] Dinas ESDM Provinsi Sumatera Barat. Daftar Daerah yang Menerima Bantuan Penerangan Listrik Energi Baru Terbarukan Provinsi Sumatera Barat Tahun 2013

[5] PT. PLN (Persero) Wilayah Sumatera Barat. (2013, September 7). Road Map Lisdes Wilayah Sumatera Barat 2012 - 2017 [Online]. Available: http://www.pln.co.id/sumbar

[6] Bhandari, Binayak dkk., "Mathematical Modeling of Hybrid Renewable Energy System : A Review on Small Hydro-SolarWind Power Generation", International Journal of Precision Engineering and Manufacturing-Green Technology, vol. 1, no. 2, hal. 157-173, April 2014.

[7] IMIDAP (Integrated Microhydro Development and Application Program), Pedoman Studi Kelayakan PLTMH. cetakan kedua, Jakarta : Direktorat Jenderal Listrik dan Pemanfaatan Energi
Departemen Energi dan Sumber Daya Mineral, 2009.

[8] Effendi, Asnal, "Pembangkit Listrik Sel Surya Pada Daerah Pedesaan", Jurnal Teknik Elektro ITP, vol. 1, no. 1, hal. 1924, Januari 2011.

[9] (2013, Maret 15). [Online]. Available: http://www.solarsuryaindonesia.com

[10] Ashok, S., "Optimised Model for Community-Based Hybrid Energy System", Jurnal Elsevier, vol. 32, hal. 1155-1164, 2007.

[11] Tanoto, Y., dkk., "Off-Grid Fully Renewable Energy with Free Capacity Shortage for Remote Electrification", Proc. IEEE, hal. 460-464, 3-4 Juni 2013.

[12] Kunaifi, "Program HOMER Untuk Studi Kelayakan Pembangkit Listrik Hibrida Di Propinsi Riau", Seminar Nasional Informatika, FTI UPN "Veteran" Yogyakarta, 2010, hal. 18-27.

[13] Juwito, A. F., $d k k$., "Optimalisasi Energi Terbarukan pada Pembangkit Tenaga Listrik dalam Menghadapi Desa Mandiri Energi di Margajaya", Jurnal Ilmiah Semesta Teknika, vol. 15, no. 1, hal. 22-34, Mei 2012.

[14] Maherchandani, J. K., dkk., "Economic Feasibility of Hybrid Biomass/PV/Wind System for Remote Villages Using HOMER", International Journal of Advanced Research in Electrical, Electronics and Instrumentation Engineering, ISSN: 2278-8875, vol. 1, issue 2, hal. 49-53, Agustus 2012.

[15] Fung, C. C., $d k k .$, "A Simulation Study on The Economic Aspects of Hybrid Energy Systems for Remote Islands in Thailand", Proc. IEEE, vol. 3, no. 3, hal. 1966-1969, 28-31 Oktober 2002.

[16] National Renewable Energy Laboratory, USA. (2012, November 28). Homer Energy Modelling Software for Hybrid Renewable Energy System [Online]. Available: http://www.homerenergy.com

[17] Lambert, Tom, $d k k$., "Micropower System Modeling with HOMER", Integration of Alternative Sources of Energy, United States of America : John Wiley \& Sons Inc., April 2006, bab 15, hal. 379-418.

[18] Akella, A. K., dkk., "Optimum Utilization of Renewable Energy Sources in a Remote 
Area", Renewable and Sustainable Energy Reviews, vol. 11, hal. 894-908, 2007.

[19] Badan Pusat Statistik Kabupaten Pesisir Selatan. (2014, Januari 1). Kecamatan Bayang Utara Dalam Angka Tahun 2013 [Online]. Available: http://pesselkab.bps.go.id

[20] Badan Pusat Statistik Kabupaten Pesisir Selatan. (2012, Desember 10). Buku Putih Sanitasi (BPS) Kabupaten Pesisir Selatan Tahun 2010 [Online]. Available: http://pesselkab.bps.go.id

[21] Bank Indonesia (2013, Desember 9). Kurs Transaksi Bank Indonesia [Online]. Available: http://www.bi.go.id

[22] Dinas PU PSDA Provinsi Sumatera Barat. MapInfo Sub DAS Bayang Janiah

[23] Dinas PU PSDA Provinsi Sumatera Barat. Data Curah Hujan Harian Stasiun Ladang Padi, Stasiun Danau Di Atas dan Stasiun Tarusan Tahun 1997-2011

[24] Dinas PU PSDA Provinsi Sumatera Barat. Data Klimatologi Harian Stasiun Gunung Nago, Stasiun Danau Di Atas dan Stasiun Surantih Tahun 2010

[25] Dinas ESDM Painan Kabupaten Pesisir Selatan. Kecamatan, Nagari dan Kampung yang Belum Mendapatkan Penerangan Listrik Kabupaten Pesisir Selatan Tahun 2013

[26] Nazir, R., $d k k$., "Renewable Energy Sources Optimization: A Micro-Grid Model Design", Energy Procedia, vol. 52, hal. 316-327, 2014.

\section{Biodata Penulis}

Novi Kurniasih, lahir di Padang tanggal 8 November 1980. Pendidikan S1 di Jurusan Teknik Elektro Universitas Bung Hatta Padang pada tahun 1999. Pendidikan S2 (Magister) di Jurusan Teknik Elektro Universitas Andalas dengan Bidang Peminatan Teknik Tenaga Elektrik. 